\title{
Creating a no-blame culture through medical education: a UK perspective
}

\author{
This article was published in the following Dove Press journal: \\ Journal of Multidisciplinary Healthcare \\ 8 August 2016 \\ Number of times this article has been viewed
}

\author{
Karl O Elmqvist ${ }^{\prime}$ \\ Maxime TJ Rigaudy ${ }^{1,2}$ \\ Jasper PVink' \\ ' Imperial College Business School, \\ Imperial College London, London, UK; \\ ${ }^{2}$ Hull York Medical School, York, UK
}

\section{Dear editor}

We read with great interest, and agree with the points made, in the Commentary by Leotsakos et al ${ }^{1}$ regarding the need to integrate patient safety into the core curricula for higher education in health care. The World Health Organisation (WHO) patient safety curriculum guide: multi-professional edition (Geneva: Switzerland 2011) appears to be an effective aid to achieve this aim, promoting the culture of patient safety internationally. In the UK, where patient safety is a defining part of quality of care, ${ }^{2}$ attempts have been made to introduce the concept of a "no-blame culture". The no-blame culture was introduced as a method to improve the quality of care by learning from mistakes, putting safeguards in place to ensure they do not occur again.

The aviation and automobile industries currently make use of real-time error reporting in order to document and analyze errors, with the objective to prevent similar occurrences in the future. In order for this to be possible in the health care setting, a noblame culture is necessary. Yet, as demonstrated by Walton, ${ }^{3}$ the extent of professional responsibility for mistakes is still not fully understood. More than one "never-event" still occurs every day in the UK National Health Service (NHS), indicating that the system is allowing for them to happen. This poses the question: why has the aviation industry achieved "Ultra Safe" status, while health care trails behind in the rate of fatal adverse events? ${ }^{4}$

We identify two reasons why the no-blame culture is not yet present in the NHS:

Leotsakos et al ${ }^{5}$ emphasize the importance of a comfortable and safe professional environment in which patient safety can be improved. Yet in the NHS, the hierarchical style of management tends to deter staff from reporting mistakes, often for fear of possible repercussions.

Walton discusses the "need to clarify where and how professional responsibility fits into the no-blame culture". ${ }^{3}$ Sources of medical mistakes are various and can be classified as human error, at risk behavior, and reckless behavior. It is commonly understood that health care practitioners should be held fully accountable for reckless behavior and adequate disciplinary action should ensue. However, for the other two, transparency through open reporting should be encouraged. As in the case of Wayne Jowett - who wrongly received a fatal spinal injection of vincristine - root cause analysis almost always identifies a system failure as the cause of these rather than one individual mistake. ${ }^{6}$ Therefore, despite the unfortunate outcomes of such
Correspondence: Karl Elmqvist Imperial College London, Exhibition Road, South Kensington, SW7 2AZ London, UK

Email karl.elmqvist12@ic.ac.uk 
events, they should be seen as crucial iterative processes in medical education.

Continuous error reporting is currently used throughout industry (with techniques such as the Toyota Production System and SixSigma) and has successfully been implemented in the health care setting. For example, at Virginia Mason Medical Centre in Seattle, Washington, a flattened hierarchy has been developed and a multidisciplinary approach taken to identify the root cause of any reported mistake. This has permitted it to become one the safest hospitals in the United States ${ }^{7}$ and their adapted use of industrial production techniques is used as a common example in patient safety management courses.

We therefore argue that to achieve the intended outcomes of the WHO Curriculum Guide in the UK, a broader culture and system change is required. Quality Improvement Projects, currently in place to improve patient safety locally are often viewed as tick-box exercises to add to a portfolio. ${ }^{8}$

Currently, medical students have the option to undertake courses such as intercalated management degrees and foundation doctors can apply to management and leadership programs. This teaching equips these future practitioners with the tools to understand and implement patient safety improvements. We would go further than Leotsakos et $\mathrm{al}^{1}$ and argue that all future medical practitioners should receive obligatory training in the management principles mentioned above. Educating the future generation of medical practitioners will allow for the much needed culture change - where reporting of mistakes should be common practice and where patient safety is central to the delivery of health care.

\section{Disclosure}

The authors report no conflicts of interest in this communication.

\section{References}

1. Leotsakos A, Ardolino A, Cheung R, Zheng H, Barraclough B, Walton M. Educating future leaders in patient safety. $J$ Multidiscip Healthc. 2014;7:381-388.

2. NHS England. [webpage on the Internet]. What do we mean by high quality care? 2016; available from: https://www.england.nhs.uk/about/ our-vision-and-purpose/imp-our-mission/high-quality-care/. Accessed May 1, 2016.

3. Walton M. Creating a "no blame" culture: have we got the balance right? Qual Saf Health Care. 2004;13:163-164.

4. Amalberti R, Auroy Y, Berwick D, Barach P. Five system barriers to achieving ultrasafe health care. Ann Intern Med. 2005;142(9): 756-764.

5. Chartered Management Institute. [webpage on the Internet]. Packer M. Monitor NHS Bullying. 2015; available from:http://www.managers.org. uk/insights/news/2015/february/whistleblower-guardians-to-monitornhs-bullying. Accessed May 1, 2016.

6. Dyer C. Teenager given wrong drug dies. The Guardian. Saturday 3 February, 2001; online, available from: http://www.theguardian.com/ society/2001/feb/03/health.uknews. Accessed May 1, 2016.

7. Virginia Mason. [webpage on the Internet]. Robinette G. Virginia Mason earns 'A' for patient safety. 2015; available from: https://www.virginiamason.org/body.cfm?id=158\&action=detail\&ref=3934. Accessed May $1,2016$.

8. Hillman T, Roueche A. Quality Improvement. BMJ Careers. 2011. Available from: http://careers.bmj.com/careers/advice/Quality_improvement. Accessed 28 May 2016.

Dove Medical Press encourages responsible, free and frank academic debate. The content of the Journal of Multidisciplinary Healthcare 'letters to the editor' section does not necessarily represent the views of Dove Medical Press, its officers, agents, employees, related entities or the Journal of Multidisciplinary Healthcare editors. While all reasonable steps have been taken to confirm the content of each letter, Dove Medical Press accepts no liability in respect of the content of any letter, nor is it responsible for the content and accuracy of any letter to the editor.

Journal of Multidisciplinary Healthcare

\section{Publish your work in this journal}

The Journal of Multidisciplinary Healthcare is an international, peerreviewed open-access journal that aims to represent and publish research in healthcare areas delivered by practitioners of different disciplines. This includes studies and reviews conducted by multidisciplinary teams as well as research which evaluates the results or conduct of such teams or health-

\section{Dovepress}

care processes in general. The journal covers a very wide range of areas and welcomes submissions from practitioners at all levels, from all over the world. The manuscript management system is completely online and includes a very quick and fair peer-review system. Visit http://www.dovepress.com/ testimonials.php to read real quotes from published authors. 